\title{
Geopolitics of Religion: How Does Religion Influence International Relations and States' Foreign Policies?
}

Hichem Kadri (Corresponding Author)

Ph.D. Candidate. Department of Political Science, International Islamic University Malaysia, Gombak, Selangor, Malaysia Email: hichem.kadri@live.iium.edu.my

\section{El Fatih Abdullahi Abdelsalam}

Professor Dr. Department of Political Science, International Islamic University Malaysia, Gombak, Selangor, Malaysia

\author{
Article History \\ Received: February 18, 2020 \\ Revised: March 3, 2020 \\ Accepted: March 9, 2020 \\ Published: March 12, 2020 \\ Copyright (C) 2020 ARPG \& \\ Author \\ This work is licensed under \\ the Creative Commons \\ Attribution International \\ (क) (5) $\mathrm{CC}$ \\ BY: Creative Commons \\ Attribution License 4.0
}

\begin{abstract}
Undoubtedly, religion is one of the main factors that increasingly contribute to the shaping of international relations. As it was in the European middle ages, religion and geopolitics have always had ties of one sort or another. Imperialism and nationalist doctrines have found purpose and justification in religious differences and, religious zealotry was functioned to be both cause and consequence of the concentration of state power and the rivalries among existing competitors. The involvement of numerous religious groups and movements in the political scene led the situation to be extremely complicated. The purpose of this article is to see to what extent religion as a soft power has a role in forming international politics. Also, to discuss the role the superpowers and regional powers play in dealing with the question of religious issues. With an argument that these issues including religious conflicts are led by international and regional powers which function these groups in a proxy war to be part of their rivalry overpower, and to achieve their national interests through their foreign policies at the cost of considerable environmental degradation and a massive death toll of people.
\end{abstract}

Keywords: Geopolitics of religion; National interest; Foreign policy; Proxy war; Soft power; Transnational ideas.

\section{Introduction}

Religion has a deep-rooted presence in the history of mankind. Many religions have survived for a long time and continued their spiritual influence on societies and communities. Calling their believers and the whole humanity to live in peace and harmony was the prominent voice of religions from their birth. In spite of this calling voice, history has shown that religion played a hotbed of bloody wars (Mustafayev, 2014). The religious idea contributed deeply to raising societies and civilizations across history as Malek Bennabi has argued (Bennabi, 2005). Religions had been used pragmatically by politicians to serve their interests by playing on the chord of the religious passion of adherents. Efforts by governments to harness the social power of religion in world politics are nothing new. Religion continued to function as part of the backdrop of Cold War geopolitics (Mandaville and Hamid, 2018).

During the middle ages, Priests and Popes incited their followers against the people of other religions to rob and purloin their properties. All this was in the name of religion. Poor peasants were inspired by the Catholic Church to start the crusade to invade rich lands in the Middle East and to settle holy lands instead (Mustafayev, 2014). The same idea was used by politicians during different periods of time and different places throughout history. The sociopolitical position of religions deteriorated following the Peace of Westphalia in 1648 where religion was privatized, and new signs of state-led secularization were largely spread out by the colonial campaigns of some European countries. In the twentieth century, religion returned to international relations in a necessary reverse process, called, de-privatization. Haynes (2010). Recently, numerous studies about the growing influence of religion in international relations have increased significantly, focusing on various kinds of transnational religious actors in the regional and international scenes; including al-Qaeda and Shi'ite networks, the Roman Catholic Church, in the Middle East (Haynes, 2010) and the Russian Orthodox Church (ROC) in Russia and Western Europe, besides other different religious groups and organizations from all over the world.

Haynes (2010) argued that the international order is being affected by some transnational religious actors, particularly the Islamic extremists and terrorists' networks (Haynes, 2010). While XU (2012) argued that religion is seen as merely a second-tier factor in the foreign policies of most countries in international politics. XU debated that religion and religious movements have no influence on the dominant role of sovereign states in the international system. Religions are incapable of neither to put norms nor serve as a basis to rebuild International Relations theory (XU, 2012). Various studies argue that religion has a connection to states' foreign policies in international relations, IR Theories, also posit that religion influence is related to politics, public opinion, violence, and the nation-state (Baumgartner et al., 2008; Bentwich, 2015; Cavanaugh, 2009; Fox, 2009; Inboden, 2008). Although many authors 
attest and agree that religion as a national and transnational factor might be influential on International affairs. They also asserted the current significance of religion in international relations, particularly the recent widespread religious resurgence from the globe (Curanović, 2012; Micklethwait and Wooldridge, 2009; Norris and Inglehart, 2011).

Norris and Inglehart (2011), developed and presented a theory of existential security which demonstrates that advanced industrial societies have been shifting toward a secular direction. Some social thinkers of the nineteenth and twentieth centuries such as Auguste Comte, Herbert Spencer, Emile Durkheim, Max Weber, Karl Marx, and Sigmund Freud besides other thinkers, all believed that religion would lose its importance in an era of the advent of industrial society (Norris and Inglehart, 2011). Reversely, the current world sees a gradual return of religious aspects in many communities and societies, and the world has now directed once again to religion.

Ostensibly, the world is moving toward an era of post-secularity, although in some parts of the world, religion is deeply unfashionable. The time secularism is seen as modern and progressive, religion is considered as traditional and backward. This is the main view of several secular politicians as Tony Blair's spin doctor Alistair Campbell who said: "We don't do God" (Ginty, 2013). Politicians are pragmatically playing on everything (religious or nonreligious) that might serve their interests and empower their political and legal legitimacy. The existential influence of religion on societies and states' foreign policies and their domestic policies is obvious. The dynamic collision of religious groups and organizations created new political orientations and approaches of these states across the world, especially in the Middle East. States with a secular orientation see religion as a double-edged sword to be reckoned with in their foreign policies' behaviors in terms of functioning religious groups and organizations in proxy wars.

In societies where there is a lack of good governance and democracy; a political, and cultural vacuum is left due to this lack and leads other actors to get involved to fill the vacuum. The most dangerous effect (situation) is the spreading of radical and extremist groups to dominate the scene. The political, social and cultural vacuum causes the appearance of extremism and contributes to spreading the dangerous background and aftermaths of ideological groups and religious fundamentalism.

Haynes (2010) focused on transnational Jihadi organizations and other Islamist extremist entities that have served to reignite the 'clash of civilizations' controversy (Huntington, 1993a) besides some extremist and moderate Christian organizations such as the Catholic Church in the West and, the Orthodox Church in the East, which move primarily with governments toward other political, social and cultural entities. The existing struggle between the U.S and its allies and transnational jihadism (Al-Qaeda, ISIS) is not seen as a simple clash of Islam versus the West, but it is a competition within Islam between a minority of extremists and most moderates (Haynes, 2010). This religious clash has been manipulated by major powers such as the U.S, Russia, and regional powers particularly Iran and Saudi Arabia, which use religion as a political tool for serving their national interests by engaging religious groups and institutions (doctrines, mosques, churches) in a proxy war under the so-called the geopolitics of religion. To what extent religion as a soft power contributes to increasing or decreasing the severity of conflicts that threaten the peace process?

\section{Religion in International Relations; (Security and Peace Process)}

Apparently, religion has regained power in international affairs, by challenging the secularization theory that emerged following the peace of Augsburg in 1555 and the Peace of Westphalia in 1648 (Schiavon, 2016). In the second half of the 20th century, religion had significantly come as a key factor in the international scene. Furthermore, religion plays a significant role in shaping international politics and international relations' theories and approaches. There is a global resurgence of religion worldwide as Huntington (1991) argued that in the modern world, religion is the central force that motivates and mobilizes people (Huntington, 1991). According to George Weigel, religion will play a more corrosive role in international conflict, also it can be a force for peace (Weigel, 1991). Scott Appleby argued that making peace requires a persistent struggle for reconciliation among people living in places prone to conflict, and religious actors can be prominent among the leaders of that struggle (Appleby, 1999). Appleby noted that religion has an irreducible role in several regional and international conflicts (Appleby, 1994) the main view as Haynes noted on how religion can be mobilized for violence and peace simultaneously (Ginty, 2013).

Peter L. Berger (American-Austrian sociologist) who was known for his limitless defense of secularization during the 1960s, then he changed his opinion by saying: "The world today, with some exceptions is as furiously religious as it ever was, and in some places more so than ever. This means that a whole body of literature by historians and social scientists loosely labeled 'secularization theory' is essentially mistaken" (Norris and Inglehart, 2011). Religion gets involved politically in a time of global religious revitalization and what Weigel called it an unsecularization of the world (Haynes, 2016). In the secularised world at the time of religious resurgence in international politics after a long time of absence. Haynes (2016) saw that the un-secularization term coined by George Weigel is not just an apolitical re-spiritualization, but it is a clear interaction between religion and politics, and this interaction is mobilized by two factors; (1) globalization process; (2) the revolution of communications. Religious transnationalism as a concept refers to the case where religious ideas exceed and give limited respect to states' boundaries, as Haynes made the point that on the opposite to religion, nationalism is often linked with a state project (Ginty, 2013).

Religion as a soft power has a serious role in forming the mentality of many societies in contemporary international affairs, a role that refers to a trend towards religious de-privatization, return of religion to the public realm in many societies (Ginty, 2013) and this return posed various challenges to international security and order in a globalized world, where culture overrides geographical borders of states. These challenges emanate from different societies and entities particularly the extremists with religious dynamics that influence global political affairs. 
Mustafayev (2014), argued that the role of religions in societies has significantly changed in the last decades. Religion has become like a spiritual institute particularly in the Western World. As the Vatican's role reduced and other churches became a mere defender of human rights after being a supporter of dictatorship (Mustafayev, 2014). What makes religious intergroup influence quite different in the Western World is their position on democracy and their susceptibility to change. In comparison to the Catholic and Orthodox Church, the Protestant Church was more reformist and adopted changes in society in a simple manner. Samuel Huntington argued in his book 'The Third Wave' that Protestantism is the only democratic religious denomination. But after the third wave of democracy, a set of fundamental changes in Christianity took place (Huntington, 1993b).

The question of religious conflicts is worldwide, with more focus on the Middle East. Thus, any addressing of religious conflicts is not possible without touching upon the Middle Eastern area. Mustafayev (2014) stated that this region helps to understand the religious interactions notably between the two prominent religious sects i.e, Jews and Muslims, also the region gives databases to study what prevents these two religious sects from living together and explains whether they peacefully coexist as described in holy scriptures, or they are in discrepancies that make the whole region unpeaceful and in imminent conflicts. Through the extrapolating of the history of the twentieth century to the present day, it can be inferred the size of the influence played by these religions on the history and the reality of international relations. The series of Arab-Israeli wars with political-religious backgrounds redrew the geopolitical map of the Middle East and, offered new probable visions about the future situation of the whole region.

The Middle East is the birthplace of several religions especially the three Monotheistic Religions (Judaism, Christianity, and Islam). Also, the Middle East is the main location where their civilizations emerged. Douglas Pratt (2017) argues that although a popular focus on Islam, extremist Jews and Christians can also enact terror and destruction. Pratt states that all religions, especially the Abrahamic have had violent pasts and paths (Pratt, 2017). Historically, many religious conflicts happened and caused trouble and intolerance rather than peaceful coexistence among the adherents of these religions in this region. According to different readings and explanations of the holy scripts for each of Jews, Christians and, Muslims, these readings were often being guided with some hermeneutic methods and approaches to vindicate their intolerant and unpeaceful acts against each other. So, depending on religious credos that cannot be waived or at least being well understood, nobody was apt to accept the other. The challenge that faced social scientists in understanding whether violence is inherent in religion or religion has been instrumentalized by secular powers to achieve their interests by imposing violent means (Kurtz, 2018).

During the second world war, the Jewish people suffered from the Nazi concentration camps which served to oppress any source of threat to the survival of the Nazi regime. As a matter of fact, in the six years of the second world war, concentration camps were not only for Jews but for any other kind of political opponents of the ruling regime such as German communists. In addition to the suffering of Jews when they had no solution but converting to Christianity as a safe way to survive from the increasing Anti-Semitism movement in Europe (Mustafayev, 2014). The Zionist movement took this event as a strong pretext to attract international compassion and, depending on religious vindications, Zionists were too eager to build the Jewish state in 1948. The Israeli state at that time needed Jews to prevent themselves from another holocaust that would happen in the future, and Judaism played an important role in the self-determination process of Jews (Mustafayev, 2014). Zionism as a movement of Jews to the land of Israel entered a long-standing conflict seen unavoidable, the thing that noticeably changed the geopolitical map of the Middle East and put it at the stake for decades. Although Zionism the ideological and political movement itself supports secularism and denies any kind of religious influence on political issues, it uses religious aspects in its political engagement throughout the world, vindicating its politics to pave the way besides the American strong support to enhance the Israeli state in Palestine and spread its sphere of influence over the region.

In comparison to Abrahamic religions which extremely involved in religious conflicts within the same religion or between the three religions, Buddhism has less involved in a series of violent conflicts and functioned violent acts to preserve the integrity of Sangha ${ }^{1}$ (Kurtz, 2018). A religious intolerance rose in recent years threatening respect for diversity. In Myanmar a set of violent attacks against the Rohingya led by Buddhist nationalism have grown in influence, what made the situation getting worse is that this Buddhist nationalism supported by the Myanmar military and the former governing party, the Union Solidarity and Development Party (Rogers, 2018). The last events in Myanmar against the Rohingya minority pushed the international community to reconsider the current humanitarian situation again and more again. In fact, religious causes were not the only causes behind this extreme hatred and intolerance, but there were other political and economic causes (the land is a reach of Gas and oil), to the extent that led the Myanmar government and army to support and encourage Buddhist extremists in their bloodthirsty acts. The question that imposes itself here is the following: How far are the causes of the hatred, fear, anger, and venom that are described as the driving forces at work linked to religious teachings and leadership? (Marshall, 2017).

On 23 December 2016, many international figures, including 11 Nobel Peace Prize laureates and various former prime ministers warned the worsening case that has all the hallmarks of recent past tragedies such as Rwanda, Darfur, Bosnia, and Kosovo." These figures called for an independent UN inquiry to establish the truth about these crimes, subsequently, the UN Human Rights Council established a fact-finding investigation (Holmes, 2016). Also, these events led the ASEAN members to hold successive meetings on this humanitarian situation that is "a matter of concern. The Rohingya issue has become one of the major topics discussed by Southeast Asian leaders and politicians.

\footnotetext{
${ }^{1}$ A community and assembly of monks (bhikshus) and nuns (bhikshunis).
} 


\section{Religion as a Soft Power in Globalised International Relations}

In general, the concept 'power' is defined as the capability of one part to influence another part and let it be succumbed to do what is required. When Nye (1990) coined the concept of soft power and presented it into international relations roughly three decades ago, at that time it was beneficial to note that hard power is the only available means to achieve objectives. Joseph Nye defines soft power as the following: 'the ability to get what you want through attraction rather than coercion or payments. It arises from the attractiveness of a country's culture, political ideals, and policies. When our policies are seen as legitimate in the eyes of others, our soft power is enhanced'(Nye, 2004).

Soft power takes different forms as the transnational ideas which have a capacity to influence international relations and politics. Transnational ideas, both religious and secular, have emerged historically in response to changing domestic and international circumstances (Haynes, 2010). The historical collision between religious and secular ideas led up to the emergence of new transnational ideas that contributed to shaping international relations such as Communism, Zionism, anti-colonialism, anti-imperialism, Pan-Africanism, Pan-Islam, national selfdetermination and environmentalism... etc (Haynes, 2010). The ability of such ideas to make their influence on reality and achieve its goals is reflective of their ability to take control over soft power. The concept 'soft power' includes every national idea with a local effect and other transnational ideas that have a significant impact on world politics and on international relations in general.

There are some kinds of ideas that significantly influence and shape the norms of the international system. International agendas and state outcomes affected differently by the represented ideas of transnational factors either religious or not religious. The time transnational ideas attract a big number of people around the world, these people can significantly influence outcomes through their efforts. Linking up on state power does not necessarily make such ideas successful or failed (Haynes, 2010).

Religious ideas have remarkably returned to international relations as a unique soft power form. The traditional secularization version needs to be renewed and updated, transnational religious ideas have obviously existed and never disappeared from international politics. Seemingly, religious ideas will overwhelm the politico-social system of communities and states across the globe. Both secular and religious ideas have pros and cons on the real-life of peoples and states, either domestically or internationally. To see how secularised ideas, differ from religious ideas in their impacts, taking an example about the human fertility rates, it is observable that in the countries which are advanced in practicing secularization show fertility rates far below the replacement level in comparison to traditional religious societies which share increasingly in the population rate of the whole world. Consequently, the cultural complex of societies and international politics have been impacted due to the expanding chasm that existed between sacred and secular versions. Studies showed that religious practices or religiosity are systematically related to (1) levels of societal modernization, human security, and economic inequality; (2) the predominant type of religious culture in any nation; (3) generational shifts in values; (4) different social sectors; and (5) patterns of demography, fertility rates, and population change (Norris and Inglehart, 2011). All these levels reverberate the deep position of religion and religiosity that is taken in almost all societies and world politics, and how the role of religion in international relations has become an important analytical focus.

Transnational religious actors play on the chord of religious ideas and doctrine as a soft power and take these ideas as an umbrella to orient it accordingly to achieve their interests. This includes international and regional actors as well, for instance, both Iran and Saudi Arabia, pretend that their foreign policies are guided by Islamic perception. Also, a large number of transnational actors, especially Islamist, Roman Catholic and Protestant Evangelical groups, where all of these religious actors bring a renewed religious dimension to world politics (Haynes, 2005) besides the Russian Orthodox Church's role in the Christendom and its impact on Russia's foreign policy even with a minimal effect.

The circumstances of the globalized world are the key factor that makes these transnational religious actors either benign or malign to take part in cross-border issues, because of their claim to be excluded from the benefits of globalization due to historical, geographical and cultural reasons (Haynes, 2010). They react to the new aspects of life that appeared simultaneously with the manifestation of globalization as a phenomenon that has tremendously changed the way of thinking and acting of various active actors and, allowed new other non-state actors to emerge and getting involved in issues of world politics. Haynes (2010), states that globalization helps to increase the links between considerable kinds of states and non-state actors both religious and secular.

Globalization attracts every intergroup and interpersonal doctrines whether they are religious or secular. The adherents of religions are extremely responsive to globalization, they deal with the phenomenon of globalization as it has two opposite impacts: (1) it is perceived as a threat to their identity; (2) it is seen as an opportunity to promote a global religion by providing a universal message to the world. ${ }^{2}$ Promoting religious ideas is operated in a form of religious transnational networks that are undoubtedly influential in international relations and politics. An example of these religious transnational networks is the cross border Islamic movements which have a soft power that empower their strength (Haynes, 2010). Fox and Sandler state that religion and religious ideas significantly influence domestic politics and consequently can influence international outcomes. Religion is considered as a motivating force that guides many policymakers across the world (Fox and Sandler, 2004), and a useful tool to be used by officials and politicians to serve their national interest wherever it is.

\footnotetext{
${ }^{2}$ Retrieved on June 11, 2019, from: https://www.crcpress.com/Religion-and-Globalization/Altglas/p/book/9780415550321
} 
Several academic attempts tried to fill the existed chasm between religious groups from all over the world. In accordance with the rising of globalization aspects, many conferences and forums have been convened to reflect the idea of interreligious dialogue and peaceful coexistence. Interreligious dialogue and greater political engagement around global challenges, including international development, conflict resolution, transitional justice all these have been encouraged by the idea of shifting religious identities (Banchoff, 2008). Although these given efforts for the sake of tackling or at least minimizing the tension of religious conflicts, interreligious competition has contributed to political conflict and put controversies over the true meaning and scope of religious freedom as Banchoff (2008) states.

\section{Religion in States' Foreign Policies (Geopolitics of Religion)}

Geopolitics of religion can be defined as an alliance between religion and politics, and this alliance is often being built in casual circumstances by overriding the geographical borders for the purpose of serving political and national objectives. States' officials in their foreign policies have different choices and tools to be used at the time they consider their national interests. Therefore, politicians use religious actors for their favor both in domestic politics and frequently across borders, and reciprocally these religious actors somehow have their own impact on the decision-makers themselves. Haynes (2016), states that "if certain religious actors manage to get the ear of key foreign policymakers through shared religious beliefs, they are wielding religious soft power". Depending on the term 'soft power' that was originally coined by Nye (1990). Soft power goes easily with people, it cooperates with them and does not compel anyone, it gets them by appealing not by force (Ginty, 2013; Haynes, 2016). Taking a look at the reality of transnational conflicts gives a clear illustration how domestic and international political issues can feed off each other to present big challenges to international order, with religious values and norms of central concern (Haynes, 2010) at the center of states' foreign policies in the actual world, only a few governments have foreign policies and more generally international relations ostensibly or significantly motivated by religion.

\subsection{International Powers: U.S and Russia}

The U.S and Russia (successor of the Soviet Union) emerged as global superpowers after the World War II period. This emergence not only set in motion the events under which the Cold War transpired but brought about the clash of the two opposing ideologies known as Capitalism and Communism (Nijman, 1992). The two superpowers set up their political presence through adopting a number of policies including those made part of "Hard Power" and those made part of "Soft Power" for extending their sphere of influence wherever their national interests exist.

\subsubsection{Religion in the United States' Foreign Policy}

Some critics point to various indicators of religious vitality in the current world. These indicators are fluctuating between the increasing popularity of the Church in the United States and the rising of New Age spirituality in Western Europe, in addition to the evangelical growing through Latin America (Norris and Inglehart, 2011) and the skyrocketing of religiosity wage in the Muslim World. As it was indicated that religious ascending in some states' foreign policies is not something new. During the cold war, the United States used to play on the chord of religion to serve its national interest. Therefore, American officials set the matter in motion by working with and promoting faith-based groups and religious proxies including some militant groups in different places in Latin America, Europe, Asia, Africa, and the Middle East in particular. During the Cold War, Europe was politically influenced by American political ideals in directing both the democratization wave and market economies. Media as Radio Free Europe used as a soft power to help to build support for both democracy and improved human rights in communist Central and Eastern Europe (Haynes, 2010). At the same time in the Middle East, the U.S was supporting Islamic Jihadists against the Soviet invasion to Afghanistan as a counterweight to atheism which was the prominent ideology during the rule of Soviet communism.

Seemingly, the idea is much relevant to the current time, in terms of the commitment of religious institutions to the foreign policies of international powers such as the United States which has known a mounting of new religious aspects coinciding with the first quarter of the 21 st century more specifically after the $9 \backslash 11$ events. The role of religion emerged in the foreign policy of the United States, with a concentration on the post-11 September 2001 ('9/11') period. For instance, the role of Evangelical Church in promoting war against the effect of Al-Qaeda and the Taliban movement in Afghanistan, also against Ba'ath regime in Iraq which as a result of a survey released on February $11^{\text {th }}, 2008$, most Evangelical leaders supported the war in Iraq and wanted the United States to "stay until the job is done". ${ }^{3}$ according to this Evangelical leaders' opinion, Iraq represents the existential threat the West has from global Islamic Jihadists. Hence, the United States goes hand in hand with its allies from the globe to put an endpoint to Al-Qaeda as long as this latter is clearly rejecting and trying to undermine the foundational values, institutions and rules of the international order and its key institutions, such as the UN and other international states, such as the U.S itself (Haynes, 2005).

Some organizations radically and fundamentally adopted religious teachings in their agendas from throughout the world like Al-Qaeda that has appeared in 1998. It was more common and well-known after the events of 11 September 2001. These events adopted by Al-Qaeda with deep fundamental religious credo and dogmas led the entire world politics map to be changed (Haynes, 2005). Such religious organizations that are classified as terrorist

\footnotetext{
${ }^{3}$ Most Evangelical Leaders Still Support Iraq War. Retrieved on June 18, 2019, from: https://www.christianpost.com/news/mostevangelical-leaders-still-support-iraq-war.html
} 
entities threaten the international security used as a direct cause by the West to get indulged in the internal affairs of some countries that are geopolitically important such as Afghanistan in 2001 and Iraq in 2003 on the charge that these countries support al-Qaeda. De facto, the western invasion of these two countries can be explained in the following one thing; "national interest" or Raison d'État, that is a set of country's goals and ambitions, whether economic, military, cultural or otherwise.

Iraq had been invaded because of its geo-economic importance. According to Paul Wolfowitz, an expert in international relations who was a strong advocate of military action against Afghanistan and Iraq and was viewed as one of the most hawkish members of the Bush administration, has gone further by claiming that the real motive was that Iraq is "swimming" in oil. ${ }^{4}$ Wolfowitz declared on 31 May 2003, "The most important difference between North Korea and Iraq is that economically we just had no choice in Iraq. The country swims on a sea of oil" (Al Taie, 2016). So, under the pretext of fighting fundamentalist religious organizations, Western countries particularly the United States by infringing international law besides misleading the international public opinion went forward to destroying Iraq and made it a new model of the failed state.

Before invading Iraq, the then American President George W. Bush used explicitly in his discourse a religious language consists of concepts particularly those of evangelical Christianity and pointed out to the United States having a calling or mission that has come from the "Maker of Heaven." Bush was the first who used religious language in his rhetoric and actions more than the previous American Presidents. This resorting to religious themes used by G.W Bush was not something of exception but an explanation of his foreign policy (Judis, 2005). Seemingly, religious conservatives have a significant influence on the foreign policy arena that however not taken in a topic of serious debate, as they have a notable force in domestic and electoral politics, (Kougentakis, 2007). Despite G.W. Bush was not that devout person as Woodrow Wilson or Jimmy Carter were, religion played a prominent role in his administration more than any of his predecessors, and the impact of his faith was evident in his personality, rhetoric, and policies (Smith, 2006). This Faith-Based Policy helped to an extent to pave the way to lead an American-led coalition on terrorism and convinced a high percentage of American public opinion to accept the war on Iraq, this war that had provoked outstanding debate among America's religious communities. During Barack Obama's administration, American officials set up the Faith-Based Policy. The Center for Faith-Based and Community Initiatives (CFBCI) stayed a solidification in the United States Agency for International Development (USAID) and President Obama showed his enthusiastic will for the initiative as the previous President did (Marsden, 2012). For disseminating a global American vision to the whole world politics, Faith-Based International Relations in coordination with political scholars tried to build on these initiatives and both called for the significant role of faith (religion) which plays in the foreign policy of the United States (Marsden, 2012).

During Trump's administration, nationalism has been the outstanding principal in Trump's understanding of global affairs. His vision of nationalism is often immersed in religious identity (Green, 2017), contrary to Obama's administration which headed for other factors as key drivers of foreign policy. Trump came back to religion to vindicate parts of his foreign policy and to expound some significant events and issues, also to explain the role of the U.S in the world politics. One of these issues is the plight of Christians in the Middle East which has been made by the media of Trump's administration as a central concern (Green, 2017), all this in order to do the groundwork for getting a deep involvement in such issues to be managed by American officials in the Middle East which are considered as a key part of the U.S sphere of influence.

\subsubsection{Religion in Russia's Foreign Policy}

Religion had known different phases in Russia's history. Religion's position fluctuated between being a pioneer in politico-social life for centuries and later as being marginalized during the rule of the communist regime (19171991). Nowadays, it is argued that religion is a crucial factor but predominately overlooked in shaping the outlook of Russia towards international relations. One of the main indicators to the importance of religion in Russia's social life is a large ambit of Russian attitudes which are influenced by religion such as Russian nationalism, Russian imperialism, the divine mission of Russian Orthodox civilization, and Russia's special approach towards Islam and Muslim World (Curanović, 2012). Curanovic argues that religion influences Russia's foreign policy in two featured ways (Huemmer, 2014), one of these ways is the functioning of religious diplomacy on the international stage by lending its support to soft diplomacy. Making, then developing strong relationships with other comparable groups outside Russia, and this subsequently helps to improve the image of the country abroad. Also, facilitating to disseminate religious diplomacy gives support to the moral dimension of Russian hybrid warfare in its rivalry game against the West by exporting "illiberal values" in foreign lands (Antunez, 2017).

With the coming of President Vladimir Putin in 2000, the Russian Orthodox Church (ROC) recaptured its vital position in the eyes of Russian officials. The ROC has somewhat shared the main views of Russia's outlook towards the world and Russia's role in international relations. Since then, the Orthodox Church went in congruence with Russia's decision-makers toward strengthening its role domestically and regionally en route to other Orthodox Churches.

ROC as a home of the world's largest Orthodox community has been taken into consideration by Moscow. In recent years, President Putin and the Archbishop Kirill have cemented an alliance for searching for common values particularly those concerning Russian national identity both domestically and internationally. The shared values

\footnotetext{
${ }^{4}$ Wolfowitz: Iraq War Was About Oil. Retrieved on June 18, 2019, from: http://www.informationclearinghouse.info/article3613.htm
} 
between Russian officials and ROC can be identified as openly traditionalist, conservative, anti-Western and antiglobalist (Antunez, 2017). Apparently, the cardinal function of ROC is to send illiberal values overseas. Russia's national identity and exceptionalism refer to anti-Western, and the anti-liberal vision of Alexander Dugin -the Kremlin's chief ideologue- who is relatively guiding Putin's geopolitical outlook towards the world. Generally, and according to this vision, Russia is neither Western nor Asian, but a unique society representing a unique set of values which are believed to be divinely inspired (Antunez, 2017). Using religion as a soft power or as a stockpile for political venture gives Russia an extra force to promote its national values and culture abroad. Depending on Russkiy Mir or the Russian World was established in 2007 for demonstrating Russia's foreign policy characterized by a dimension of expansionism and messianism where there are shared points between Moscow and the Russian Orthodox Church (ROC). Moreover, adopting such a messianic worldview could be served as an example for confronting the secularised range of the West.

In fact, any attempt to give a comprehensible explanation to the existing relations between Russia's foreign policy and the ROC is still under search. For instance, ROC concurs to be sometimes used by the Kremlin as a political and diplomatic tool in such international political affairs when Russian involvement could otherwise be considered a Russian intervention (Tserpitskaya, 2005). For providing ideological justifications for Russia's agenda, ROC as other institutions are functioned by Russian politicians to be a pro-government think tank (Petrenko, 2012). Therefore, the Church has supported and provided justification for Russia's official position on Western military interventions in former Yugoslavia, Iraq, Afghanistan, and, Syria. ROC supported last Russia's intervention in Syria due to two reasons: (1) declaring war on terrorism and leading anti-terror front, (2) protecting the Christians of the Middle East as the Church sees this task as a part of its responsibility (Weir, 2015).

\subsection{Regional Powers: Iran and Saudi Arabia}

Islam is one of the main influential religions in the world. The pre-eminent wage of Islam in the international scene, in which it has been a prominent non-state actor also has transnational networks that have a heavyweight informing world politics. Recently, Islam has inclined to focus on how religion became a source of political, social and even military simulation and how it is employed by politicians to be their ideological fortress.

What puts these Islamic transnational networks in motion, is the involvement of a number of governments inclusive of those often the cynosure of Islamist activism. Governments that chose to use Islam as a key constituent of their own foreign policy behavior, particularly Iran and Saudi Arabia. For years, both these two countries endeavored to spread their sphere of influence on the account of various social and religious values. By exploiting religion to be in running order, Iran frequently used public diplomacy outreach in countries with weighty Shi'ia populations. On the other side, Saudi government officials spent billions of dollars on propagating activities of the Sunni doctrine around the world for more than the past half-century (Mandaville and Hamid, 2018). The state-help for transnational religious activism carries political ambitions to defend and secure its regime's survival.

These are the two leading examples of the longstanding alliance between politics and religion in the Middle East. As a matter of fact, nearly all the Muslim countries have troubled with the intervention of religious leaders in politics (Mustafayev, 2014) the thing that provoked insecurity and unsteadiness inside these countries. Furthermore, the covetous vision of those religious leaders put Islam at the stake of misinterpretation.

Iran and Saudi Arabia are key power brokers in the Middle East. Their antagonistic bilateral relations continue to aggravate the geopolitical status of the whole region. Iranian and Saudi governments vex against each other in a sharp rivalry for extending their sphere of influence in the region. What is worse is that this rival battle characterized in the entirely sectarian form of an ingrained hostility between Sunna and Shi'ia. The outstanding rivalry between Iran and Saudi Arabia which the two regional powers brought religious proxies into play, has taken various forms particularly with the recent events of the so-called Arab Spring. The Saudi-Iranian vying for domination makes the geopolitical dynamic complex of the region difficult to be understood (Wastnidge, 2018) also the religious dimension of this rivalry, calls for looking at how the Islamic outreach strategies of the two governments have evolved in response to changing regional and global environments (Mandaville and Hamid, 2018).

\subsubsection{Religion in Iran's Foreign Policy}

The crucial aspects of the Iranian regime are the employment of Shi'ism to serve its national interests in the region and all over the Muslim World. The exporting of the Islamic revolution principles is often taking unclear forms. The background and the main impacts of the Islamic revolution on the region led to the first Gulf War (19801988) and made the revolution slogan "Exporting the revolution principles" significantly important and attractive. For providing more magnitude of soft power and leverage in the Muslim World especially in the underdeveloped and poverty-stricken communities, Iran endeavors to serve its national interest through promoting its values besides its revolutionary ideas by means of public diplomacy (Kamal and Ra'ees, 2018). Accordingly, myriad deprived and poor religious and ethnic groups are magnetized to accept the Iranian offers. Kamal and Ra'ees (2018), argue that Iran is an ideological state that relied on the Shia belief system. Iran's foreign policy is driven by its political ideology where the axial objective is to promote Shia's ideological system in the whole Muslim World. Therefore, there is a close relationship between Iran's national interests and the activities of some religious institutions supported by the Iranian government- such as the Imam Khomeini Relief Committee (IKRC). This institution besides others is used within Tehran's foreign policy objectives to promote Shi' ism in varied Muslim countries such as Afghanistan (Kamal and Ra'ees, 2018), Iraq, Syria...ect. In addition to the activities of the Islamic Culture and Relations Organisation (ICRO) and Ahl ul-Bayt World Assembly (Wastnidge, 2018). 
Some crucial regional developments helped Iran to use its transnational links to Shia communities mainly the ouster of Saddam's regime and the coming of a new friendly government in Iraq (Wastnidge, 2018). Moreover, Iran's position as the Shi'a metropole gives it the ability to use its transnational religious networks as and when needed to serve its national interest. Iran's support to Hizballah where the religious links with Lebanese Shi'a are well-documented and go back centuries, as do religious ties to the Shi'a populations in Bahrain, India, Pakistan and Afghanistan (Wastnidge, 2018) as well as the vindication is remarked in the military operations and the fight against ISIS in both Syria and Iraq, all this refers to Iran's religious plan that is to help to provide legitimacy for Iran's behaviors in terms of its political activities in the region. Iran's influence in Iraq and Syria clearly exists in different forms particularly the educational system of these two countries and other countries that are in Iran's sphere of influence.

Religious leaders of the Iranian Islamic revolution in 1979 have employed people as a shield in attempting to overthrow the monarch dictator rule of Shah Reza Pahlavi, to be replaced by a theocratic government led by a supreme religious leader called Ruhollah Khomeini. Citizens who have been used to topple the monarchy found themselves under a new despotic system under a religious umbrella. For the sake of promoting its doctrinal tenets to serve its national interest, the theocratic system of Iran continued to undermine the political situation, to destabilizing activities in the Middle East and to support terroristic groups to maintain its power in the region (Mustafayev, 2014). Reciprocally, the devastating political and military acts accompanied by religious vindications of Iran create counteraction by another conservative theocratic religious state called Saudi Arabia.

\subsubsection{Religion in Saudi Arabia's Foreign Policy}

A country with enormous oil and gas reserves enhance political leaders to expand their religious interests in the whole region, in the matter of getting involved in the internal affairs of some Muslim countries. Concerning the way followed to realize their policies and strategies in these countries, the way which debilitates and causes instability of the situation in the region.

Saudi Arabia and Iran are building their political legitimacy depending on religion, they tend to keep regime survival as indistinguishably linked to religious legitimacy. As both countries are considered authoritarian and seen by others as theocratic regimes where religion and religious institutions play a significant role in legitimizing their political presence. Furthermore, religion is employed as a proxy tool and religious doctrines have become a space for exhibiting conventional geopolitical rivalries between Saudi Arabia and Iran. the religious dimension of the SaudiIranian vying and antagonism is undoubtedly clear. The Islamic outreach policies of Saudi Arabia and Iran have evolved in response to changing regional and global environments (such as Saudi Arabia's view of Shia Islam as an avatar of Iran and Iran's view of Sunni Islam as an avatar of Saudi Arabia). Meanwhile, both Saudi Arabia and Iran are promoting extremism in Syria and Iraq as proxy war areas at the time Saudi and Iranian officials pretend to look with favor on moderate Islam. The Syrian demonstrations against the repressive regime were the domino effect of the Arab Spring (Mustafayev, 2014). The civil confrontation came after these demonstrations were exploited and turned into sectarian conflict between Sunna and Shi'ia. A set of proxy wars led by Saudi Arabia and Iran where the two countries incited radical groups and terroristic organizations such as Al Qaida, ISIS, and Hizbullah (Mustafayev, 2014).

Use of Wahhabism as a religious sect besides the calling for some shining slogans such as "spreading Wasatyyah towards Muslim world" (closely to Iran's view). Although the Saudi religious effects and influence are not clear to be understood the way anybody normally thinks. Mohammad bin Salman said that they used the Saudifunded spread and export of Wahhabism just for a political purpose (Shahtahmasebi, 2018). Wahhabism is used as a counter-ideological tool to undermine every religious movement that may threaten the survival of the Saudi Kingdom, particularly the Muslim Brotherhood the prominent Islamic movement in the Muslim Wolrd. This to mention that the Muslim Brotherhood movement is considered by Saudi Arabia as Iran's ally.

Some current literature on the kingdom fundamentally sees that the establishment of modern Saudi Arabia comes as a result of an aggressive Wahhabi ideology supported by a politically, and inspired religion. Historical studies that deal with relations between Saudi Arabia and the United Kingdom reveal a shred of close documentary evidence which demonstrates that the territorial expansion of Saudi state in the limited period between 1914 to 1927 was the result of the UK's imperial policy to achieve its political and military goals in the Middle East (Enazy, 2009). Apparently, both Abdelaziz Ibn Saud (the founder of the third Saudi State) and Wahhabism had been used as a political instrument to achieve Britain's objectives in the region (Enazy, 2009). Wahhabism as a politicized ideology was a cornerstone to build the current Kingdom of Saudi Arabia with a (un) holy alliance between politics and religion.

By the creation of Saudi Kingdom in 1932, Saudi officials tended to promote moderate Islam as a way for winning satisfaction of the West and at the same time showing Saudi endeavor to lessen the increasing danger of radicalism and extremism and asserting also the Saudi contributions to the international efforts in leading the war on terrorism, a phenomenon that threatens the international common security. Religion is merely a functional tool for KSA's foreign policy, it is used as long as it serves the interests of the Saudi foreign policy. When Saudi officials find a better alternative to religion and religious institutions they will put them into oblivion. Time will show and judge!!

\section{Conclusion}

To sum up, religion is undoubtedly considered as one of the key factors in understanding international relations, whether its impact is tremendous or tiny. Religion is still important in studying international relations and 
particularly in security and peace studies. All the outstanding religions are the benchmark of the daily way of people's life. Typically, religions invite humanity to tolerate diversities and respect human rights, but on the ground, it is the opposite. Religion had been marginalized for a long time after the Peace of Westphalia in 1648, then after the outbreak of the French revolution in 1789, where the first secular state emerged in France, then under the communist regime rule in the ex-Soviet Union. In a post-secular epoch, Religion took place again but in a new form in comparison to the last era, where the position of religion was quite different. It is a useful and effective soft power employed by decision-makers in their foreign policies to achieve their national interests and, to spread their sphere of influence abroad regardless of whether they are sincere in their religiosity or not.

\section{References}

Al Taie, S. (2016). The 2003 War on iraq: Purposes and motivations, an analytical view. Available: DOI: 10.13140/RG.2.1.3230.1684

Antunez, J. C. (2017). The role of religion and values in russian policies: The case of hybrid warfare. Gesi analysis. Available: https://www.seguridadinternacional.es/?q=en/content/role-religion-and-values-russian-policiescase-hybrid-warfare

Appleby (1994). Religious fundamentalisms and global conflict. Headline Series No. 301: ERIC.

Appleby (1999). The ambivalence of the sacred: Religion, violence, and reconciliation. Rowman and Littlefield Publishers.

Banchoff, T. (2008). Introduction: Religious pluralism in world affairs. Religious pluralism, globalization, and world politics. 1.

Baumgartner, J. C., Francia, P. L. and Morris, J. S. (2008). A clash of civilizations? The influence of religion on public opinion of US foreign policy in the Middle East. Political Research Quarterly, 61(2): 171-79.

Bennabi, M. (2005). Les conditions de la Renaissance: problème d'une civilisation: Editions ANEP. Available: https://www.fichier-pdf.fr/2015/09/09/bennabi-malek-les-conditions-de-la-renaissance/bennabi-malek-lesconditions-de-la-renaissance.pdf

Bentwich, N. (2015). The religious foundations of internationalism: a study in international relations through the ages. Routledge.

Cavanaugh, W. T. (2009). The myth of religious violence: secular ideology and the roots of modern conflict. Oxford University Press Oxford. 3.

Curanović, A. (2012). The religious factor in russia's foreign policy: Keeping god on our side. Routledge.

Enazy, A. H. (2009). Saudi wahhabi Islam in the service of uncle sam. Available: https://www.mei.edu/publications/saudi-wahhabi-islam-service-uncle-sam

Fox, J. (2009). Integrating religion into international relations theory. Routledge handbook of religion and politics. 273-92.

Fox, J. and Sandler, S. (2004). Bringing religion into international relations. Springer.

Ginty, R. M. (2013). Religious transnational actors and soft power. The Round Table, 102(3): 311-12. Available: doi: $10.1080 / 00358533.2013 .793567$

Green, E. (2017). How religion made a global comeback in 2017. The Atlantic: Available: https://www.theatlantic.com/international/archive/2017/12/religion-trump/548780/

Haynes, J. (2005). Religion and international relations after '9/11. Available: https://doi.org/10.1080/13510340500126814

Haynes, J., 2010. "Causes and consequences of transnational religious soft power." In Paper presented at the Political Studies Conference Proceedings.

Haynes, J. (2016). Religious transnational actors and soft power. Routledge.

Holmes, O. (2016). Nobel laureates warn aung san sun kyi over the 'ethnic cleansing' of rohingya, the guardian. Available: $\quad$ http://www.theguardian.com/world/2016/dec/30/nobel-laureates-aung-san-suu-kyi-ethniccleansing

Huemmer, A. (2014). The religious factor in russia's foreign policy. Taylor and Francis.

Huntington, S. P. (1991). Religion and the third wave. The National Interest, (24): 29-42. Available: https://www.jstor.org/stable/42894744

Huntington, S. P. (1993a). The clash of civilizations? Foreign Affairs: 22-49. Available: http://ikesharpless.pbworks.com/f/Samuel+Huntington,+The+Clash+of+Civilizations.pdf

Huntington, S. P. (1993b). The third wave: Democratization in the late twentieth century. University of Oklahoma Press. 4.

Inboden, W. (2008). Religion and American foreign policy, 1945-1960: the soul of containment. Cambridge University Press.

Judis, J. (2005). The chosen nation: The influence of religion on US foreign policy. Insight Turkey. 64-72.

Kamal, A. M. B. and Ra'ees, W. (2018). Iran's aid diplomacy in afghanistan: The role of imam khomeini relief committee. Contemporary Review of the Middle East, 5(4): 308-26.

Kougentakis, A. (2007). How the influence of religion makes the foreign policy of the Bush administration revolutionary, and how this has affected our relations with European allies. University of Pennsylvania: Available: https://repository.upenn.edu/cgi/viewcontent.cgi?article=1081\&context=curej

Kurtz, L. R. (2018). The warrior and the pacifist: Competing motifs in buddhism, judaism, christianity, and islam. Routledge. 
Mandaville, P. and Hamid, S. (2018). Islam as statecraft: How governments use religion in foreign policy. Foreign Policy at Brookings.

Marsden, L. (2012). Bush, Obama, and a faith-based US foreign policy. International Affairs, 88(5): 953-74.

Marshall, K. (2017). Religious factors in the rohingya crisis: A horrific state of limbo. Available: https://www.huffingtonpost.com/entry/religious-factors-in-the-rohingya-crisis-ahorrific_us_59ef4b20e4b0b8a51417bd3e

Micklethwait, J. and Wooldridge, A. (2009). God is back: How the global rise of faith is changing the world. Allen Lane: London.

Mustafayev (2014). The role of religions in conflicts. Available: https://www.geopolitica.info/the-role-of-religionsin-conflicts/

Nijman, J. (1992). The limits of superpower: the United States and the Soviet Union since World War II. Annals of the Association of American Geographers, 82(4): 681-95. Available: https://doi.org/10.1111/j.14678306.1992.tb01723.x

Norris, P. and Inglehart, R. (2011). Sacred and Secular: Religion and politics worldwide. Cambridge University Press.

Nye, J. S. (1990). Soft power. Foreign Policy, (80): 153-71. Available: DOI: 10.2307/1148580

Nye, J. S. (2004). Soft power: The means to success in world politics. New York, United States.

Petrenko, G. (2012). Influence of the russian orthodox church on russia's foreign policy. Available: https://ecpr.eu/filestore/paperproposal/a0fa90ec-d2cb-498a-ae34-31396d87b8cf.pdf

Pratt, D. (2017). Religion and extremism: rejecting diversity. Bloomsbury Publishing.

Rogers, B. (2018). Rejecting religious intolerance in South-east Asia. Journal of Southeast Asian Human Rights, 2: 208-35. Available: doi: 10.19184/jseahr.v2i1.7587

Schiavon, E. (2016). How religion influences the foreign policy of countries. The us-israel special alliance. Università Ca'Foscari Venezia.

Shahtahmasebi, D. (2018). Saudi crown prince america asked us to spread the ideology of isis. Available: https://www.newsclick.in/saudi-crown-prince-america-asked-us-spread-ideology-isis

Smith, G. S. (2006). Faith and the presidency from george washington to george w. Bush. Oxford University Press.

Tserpitskaya, O. L. (2005). Russian orthodox church at the russian state: Cooperation in terms of foreign policy. Ph.D. In Russian, Церпицкая О.Л. Русская Православная Церковь и Российское государство: основы внешнеполитического взаимодействия.- СПб.; 2005. http://www.soctheol.ru/avtor art.php?id=172

Wastnidge, E. (2018). Religion and geopolitics in Iranian foreign policy. The Foreign Policy Centre.

Weigel, G. (1991). Religion and peace: An argument complexified. The Washington Quarterly, 14(2): 27-42.

Weir, F. (2015). Is Russia's intervention in Syria a 'holy war'? Russian Orthodox Church: 'yes'. Available: https://www.csmonitor.com/World/Europe/2015/1123/Is-Russia-s-intervention-in-Syria-a-holy-warRussian-Orthodox-Church-yes

XU, Y. (2012). Religion and international relations in the age of globalization. Journal of Middle Eastern and Islamic Studies (in Asia), 6(4): 19-50. 